\title{
Passivity and Semiconducting Behavior of a High Nitrogen Stainless Steel in Acidic NaCl Solution
}

\author{
Yanxin Qiao, ${ }^{1}$ Xiang Cai, ${ }^{1}$ Jie Cui, ${ }^{2}$ and Huabing $\mathrm{Li}^{3}$ \\ ${ }^{1}$ School of Materials Science and Engineering, Jiangsu University of Science and Technology, Zhenjiang 212003, China \\ ${ }^{2}$ School of Naval Architecture and Ocean Engineering, Jiangsu University of Science and Technology, Zhenjiang 212003, China \\ ${ }^{3}$ School of Metallurgy, Northeastern University, Shenyang 110004, China
}

Correspondence should be addressed to Yanxin Qiao; yxqiao@imr.ac.cn

Received 7 September 2016; Accepted 17 October 2016

Academic Editor: Paolo Ferro

Copyright (C) 2016 Yanxin Qiao et al. This is an open access article distributed under the Creative Commons Attribution License, which permits unrestricted use, distribution, and reproduction in any medium, provided the original work is properly cited.

\begin{abstract}
The passivity and semiconducting behaviors of a high nitrogen-containing nickel-free stainless steel (HNSS) in $0.05 \mathrm{~mol}_{2} \mathrm{~L} \mathrm{H}_{2} \mathrm{SO}_{4}$ $+0.5 \mathrm{~mol} / \mathrm{L} \mathrm{NaCl}$ have been investigated. Results indicated that HNSS offered excellent pitting corrosion resistance in corrosive environments. Three corrosion potential values were observed in potentiodynamic polarization response, indicating the existence of an unstable system. The current transient and Mott-Schottky plots demonstrated that the stability of passive films decreased with the increase of applied potentials. The angle resolved X-ray photoelectron spectrometric results revealed that the primary constituents of passive films formed in $0.05 \mathrm{~mol} / \mathrm{L} \mathrm{H}_{2} \mathrm{SO}_{4}+0.5 \mathrm{~mol} / \mathrm{L} \mathrm{NaCl}$ solution were composed of iron oxides, manganese oxides, $\mathrm{Cr}_{2} \mathrm{O}_{3}$, and $\mathrm{Cr}(\mathrm{OH})_{3}$. Meanwhile, it indicated that molybdenum oxides did not exist in the oxide layer, but chloride ions were present in the passive films.
\end{abstract}

\section{Introduction}

Since the first report about the use of nitrogen as an alloying element in 1938, research on the nitrogen-containing stainless steels has been widely carried out [1]. As a beneficial alloying element, the effect of nitrogen on mechanical properties and corrosion resistance of stainless steels have been deeply investigated since the 1990s. It has been reported that the addition of nitrogen could drastically increase both the yield strength and ultimate tensile strength without sacrificing the ductility and toughness [2-6]. Moreover, the addition of nitrogen could also improve the corrosion, corrosion fatigue, and stress corrosion cracking resistance of stainless steels [5, 7-13]. Therefore, nitrogen is a strong austenite stabilizing element and is expected to substitute for relatively expensive element of nickel to make HNSS a resource-saving materials.

With these increasing demands, it is necessary to investigate the passive behavior and properties of passive films of the HNSS. Generally, the passive films formed on stainless steels are mainly composed of metal oxides and/or hydroxides which envisaged semiconductors and ranged from $1 \mathrm{~nm}$ to $10 \mathrm{~nm}$ in thickness. The electrical properties of which are expected to be crucially important for understanding the protective characters against corrosion. Passive films formed on surfaces of stainless steels have been described as a bilayer structure of ( $\mathrm{Cr}(\mathrm{III})$ and $\mathrm{Fe}(\mathrm{III}))$ mixed inner layer enriched with $\mathrm{Cr}_{2} \mathrm{O}_{3}$ and $\mathrm{Cr}$-hydroxide outer layer. Previous results revealed that the passive films on stainless steels were mainly composed of $\mathrm{Cr}_{2} \mathrm{O}_{3}, \mathrm{Cr}(\mathrm{OH})_{3}, \mathrm{MoO}_{2}, \mathrm{MoO}_{3}, \mathrm{Fe}_{2} \mathrm{O}_{3}, \mathrm{Fe}_{3} \mathrm{O}_{4}$, $\mathrm{FeOOH}$, and so forth, which was caused by either cation transport through interstitial diffusion or anion diffusion inwards the metal $[8,12,14-18]$. However, the composition of films are influenced by both the chemical composition [8] and $\mathrm{pH}$ value of the solution $[12,16,19]$. Moreover, the formed films could affect their semiconducting properties and protection ability [20]. In the investigation of passive films on HNSS, Fu et al. reported that the ratio between Cr-oxide and Cr-hydroxide increased with the nitrogen concentration [12]. Ningshen et al. found that the nitrogen content influenced the semiconducting nature of the passive film and the oxide layers in passive films could be modified by nitrogen additions [16]. Although some attempts were made to correlate the electronic nature of passive films with their protectiveness on stainless steels, it still lacks a systematical investigation about 


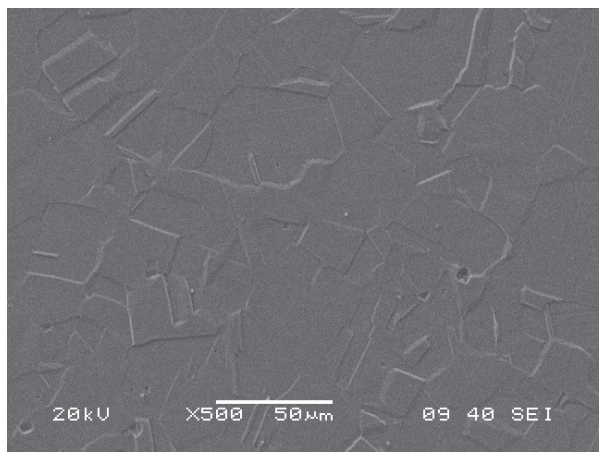

(a)

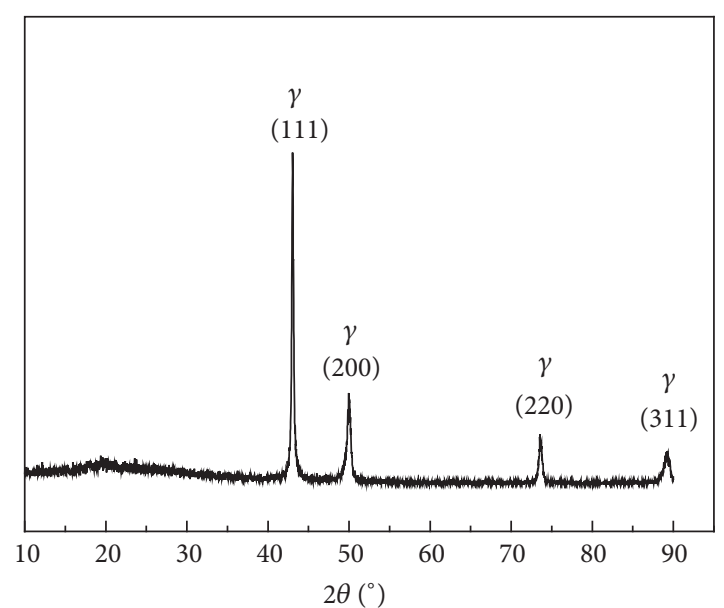

(b)

FIgURE 1: Microstructure (a) and X-ray diffraction pattern (b) of the investigated HNSS.

the electronic properties of passive films of HNSS. In this work, the target is to investigate the passivity behavior and semiconducting properties of surface films formed on a high nitrogen-containing nickel-free stainless steel.

\section{Experimental Procedures}

2.1. Material. The HNSS used in this study was supplied by Northeastern University, Shenyang, China. The chemical compositions (in wt.\%) of the alloy are C 0.058, Si 0.19, Cr 19.55, Mn 19.51, Mo 2.26, $P \leq 0.03$, S 0.003, Al 0.04, N 0.96 , and Fe balance. A rolled sheet $(220 \mathrm{~mm} \times 120 \mathrm{~mm} \times$ $5 \mathrm{~mm}$ ) of HNSS was annealed at $1150^{\circ} \mathrm{C}$ for $1 \mathrm{~h}$ and followed by water quenching to room temperature. The HNSS sample was polished down to a diamond finish of $1.5 \mu \mathrm{m}$ and then electrolytically etched in $10 \%$ oxalic acid reagent at $12 \mathrm{~V}$ for $90 \mathrm{~s}$ for the microstructural observations. Figure 1 shows SEM observations of the typical microstructure of HNSS used in the present study. It can be seen that HNSS consisted of austenite grains and some twins. No precipitates exist inside austenite grains and at grain boundaries. XRD analysis shows that HNSS is mainly composed of austenite $(\gamma)$ phase. The sheet was cut into coupons of $10 \mathrm{~mm} \times 10 \mathrm{~mm} \times 5 \mathrm{~mm}$ and the working surfaces of coupons exposed to test solutions was $10 \mathrm{~mm}^{2}$. Moreover, all the unexposed area was coated with paraffin-resin mixture. Before the measurements, the surfaces of working electrode were polished with a series of silicon carbide abrasive paper to a finish grit of $800 \#$. After that, samples were placed in an ultrasonic acetone bath for about five minutes and then air-dried.

2.2. Electrochemical Measurements. All electrochemical measurements were performed in a standard three-electrode system in a $1.5 \mathrm{~L}$ glass cell using a model Cortest CS350 potentiostat/galvanostat. A three-electrode cell setup consisting of a Pt counterelectrode, a saturated calomel electrode (SCE), and specimen as working electrode was employed.

The test electrolytes were $0.1 \mathrm{M} \mathrm{NaCl}, 0.5 \mathrm{M} \mathrm{NaCl}$, and $0.05 \mathrm{M} \mathrm{H}_{2} \mathrm{SO}_{4}+0.5 \mathrm{M} \mathrm{NaCl}$. The purities of all chemicals were the analytical grade. Experiments were carried out at room temperature in naturally aerated solution without stirring. Polarization curves were measured at a sweep rate of $0.333 \mathrm{mV} / \mathrm{s}$. The anodic current transient curves were recorded at potentials ranging from -0.1 to $0.2 \mathrm{~V}_{\mathrm{SCE}}$ to investigate the repassivation kinetic of tested samples. MottSchottky measurements were started from $-1600 \mathrm{mV}$ to $1600 \mathrm{mV}$ with a sweep rate of $20 \mathrm{mV} / \mathrm{s}$. Mott-Schottky analysis was carried out as follows. Each specimen was reduced potentiostatically at $-1.0 \mathrm{~V}_{\mathrm{SCE}}$ for $120 \mathrm{~s}$ and then polarized at a desired potential for $60 \mathrm{~min}$ to form a steady passive film. The excitation voltage was sine wave modulated signal of $10 \mathrm{mV}$. Moreover, a step rate of $20 \mathrm{mV} / \mathrm{s}$ and a frequency of $1000 \mathrm{~Hz}$ were employed [21]. The measurement of capacitance-voltage profile for passive films formed at different potentials was carried out on the same sample. All the electrochemical measurements were repeated at least triple to ensure the good reproducibility.

Surface analyses of passive films were performed using an conventional angle resolved ESCALAB250 X-ray photoelectron spectrometric (ARXPS) with a monochromatic Al $\mathrm{K} \alpha(1486.6 \mathrm{eV})$ radiation source. The photoelectron take-off angle being used is $0^{\circ}$. The binding energy scale was calibrated to give an $\mathrm{Au} 4 \mathrm{f} 7 / 2$ line position at $83.98 \mathrm{eV}$. Depth profile was measured using the argon ion bombardment with ion energy of $0.5 \mathrm{keV}$. The measured current of samples during the depth profile experiment was $0.5 \mathrm{~mA}$, and the bombardment area was $2 \mathrm{~mm} \times 2 \mathrm{~mm}$. Peak identification was performed by reference to a database of XPS.

\section{Results and Discussion}

3.1. Potentiodynamic Responses. Figure 2 shows potentiodynamic polarization curves of HNSS measured in three solutions at room temperature. In this work, no pitting corrosion was detected for all conditions, indicating that HNSS has a relatively superior pitting corrosion resistance. Moreover, it can be seen that HNSS exhibited a transition from active to passivation in $0.1 \mathrm{~mol} / \mathrm{L}$ and $0.5 \mathrm{~mol} / \mathrm{L} \mathrm{NaCl}$ solutions. 


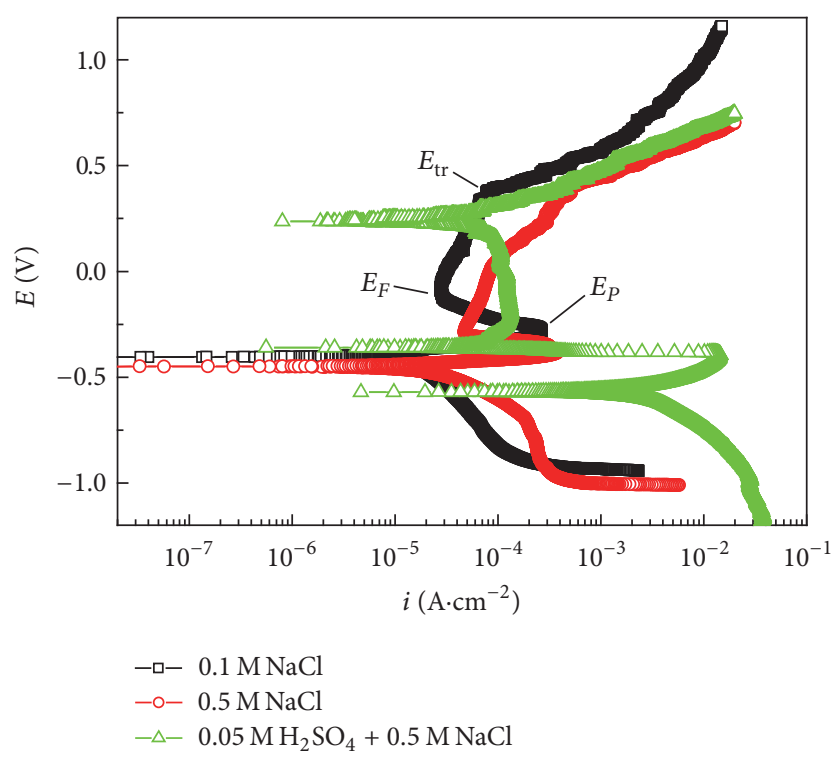

FIGURE 2: Potentiodynamic polarization curves for HNSS tested in different solutions. $E_{P}$ : passivation potential; $E_{F}$ : Flade potential; $E_{\mathrm{tr}}$ : transpassive potential.

The corrosion potentials $\left(E_{\text {corr }}\right)$ of HNSS in $0.1 \mathrm{~mol} / \mathrm{L}$ and $0.5 \mathrm{~mol} / \mathrm{L} \mathrm{NaCl}$ were -0.41 and $-0.38 \mathrm{~V}_{\mathrm{SCE}}$, respectively. On the other hand, it clearly shows that the electrochemical corrosion behavior of HNSS is significantly affected by the concentration of $\mathrm{Cl}^{-}$. Additionally, the polarization curves in anodic part can be divided into four regions, at which the current densities change suddenly. When the test started at $E_{\text {corr }}$ and scanned towards the positive direction, an anodic current will increase almost lineally with the increased potentials, indicating the presence of a state of active dissolution. At characteristic potential $E_{p}$ (passivation potential), the current density reached a maximum value. With the potential increasing, the current density decreased and reached a minimum value at passive potential $\left(E_{F}\right)$. It has been reported that the absorbed iron hydroxide species into the passive oxide film could take place in this potential range [22]. The HNSS is in a state of passivation in the potential region ranging from $E_{F}$ to $E_{\text {tr }}$ (transpassive potential). In this region, the current density increases with the increasing of potential, indicating the stability degradation of passive film. When the potential is higher than $E_{\mathrm{tr}}$, a new increase in the current will start. In this region, the passive film can be oxidized and accompanied with an increasing in corrosion rate or the start of oxygen evolution $[23,24]$.

Meanwhile, in $0.05 \mathrm{~mol} / \mathrm{L} \mathrm{H}_{2} \mathrm{SO}_{4}+0.5 \mathrm{~mol} / \mathrm{L} \mathrm{NaCl} \mathrm{solu-}$ tion, three corrosion potentials, at which the anodic current density is equal to the cathodic current density, existed in the active, active-passive, and passive regions, respectively. This finding is consistent with the results reported by Qiao et al. [9], Fu et al. [12], and Ye et al. [18]. It has been reported that the potentiodynamic polarization curves of stainless steels in acidic $\mathrm{NaCl}$ solution exhibited three corrosion potentials, which is mainly ascribed to the existence of an unstable system. Three corrosion potentials were determined to be

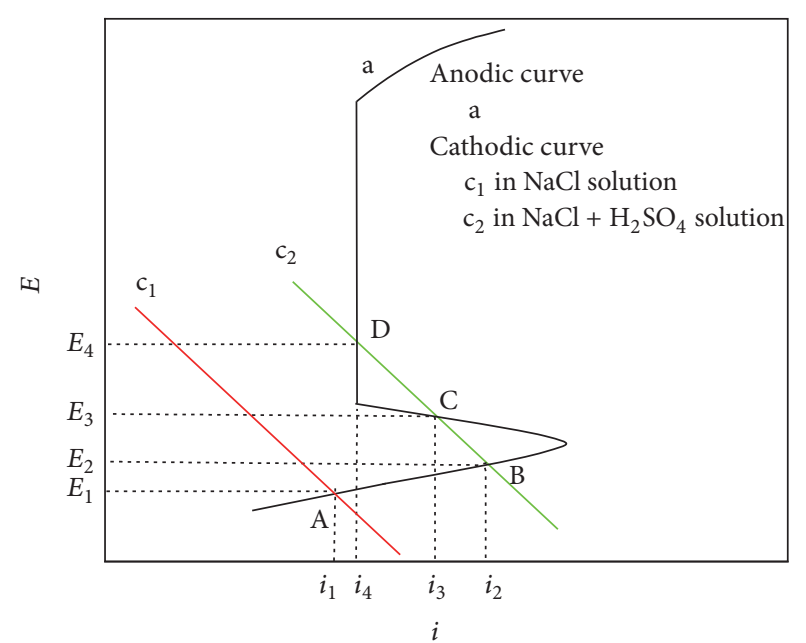

FIGURE 3: Schematic diagram of ideal polarization curves for HNSS tested in different solutions.

$-0.57,-0.36$, and $0.25 \mathrm{~V}_{\mathrm{SCE}}$, respectively. The current density remained constant in the potential region between -0.30 and $0.20 \mathrm{~V}_{\mathrm{SCE}}$, indicating that HNSS was in a state of passivation. Therefore, the potential range of -0.2 to $0.2 \mathrm{~V}_{\mathrm{SCE}}$ was selected to investigate the passivity behavior and semiconducting properties of HNSS. Since no obvious pitting potentials were observed, HNSS could offer excellent pitting corrosion resistance in severe corrosive environments

Figure 3 illustrates the ideal schematic diagrams for the corrosion behavior of HNSS in tested solutions based on the mixed potential theory. In $0.1 \mathrm{~mol} / \mathrm{L}$ and $0.5 \mathrm{~mol} / \mathrm{L} \mathrm{NaCl}$ solutions, the anodic and cathodic curves intersect at point $A$ in active region. That is to say, there is only one corrosion potential $\left(E_{1}\right)$ in the potentiodynamic polarization curve. The electrochemical state of HNSS in $0.05 \mathrm{~mol} / \mathrm{L} \mathrm{H}_{2} \mathrm{SO}_{4}+$ $0.5 \mathrm{~mol} / \mathrm{L} \mathrm{NaCl}$ solution is assumed to be decided by the anodic and cathodic curve at points B, C, and D in Figure 3, and the possible corrosion potentials are defined as $E_{2}, E_{3}$, and $E_{4}$, respectively.

3.2. Current/Time Transient Measurements. The $i$ - $t$ transients of HNSS obtained at various potentials in $0.05 \mathrm{~mol} / \mathrm{L} \mathrm{H}_{2} \mathrm{SO}_{4}$ $+0.5 \mathrm{~mol} / \mathrm{L} \mathrm{NaCl}$ are shown in Figure 4 . The value of transient current could be a sum of currents resulted from the film formation and dissolution of alloy into the solution. For all the applied potential values, at the initial stage, the current density decreased rapidly with the increased time. This may attributed to the nucleation and growth of passive films. During this stage, the rate of film formation was higher than the dissolution rate of metal. At an applied potential of $-0.2 \mathrm{~V}_{\mathrm{SCE}}$, the current densities decreased continuously with time and subsequently achieved steady state. Such typical and smooth-shaped curve indicates that a stable passive film is formed on the surface with no breakdown occurrence during the entire measurement period. The current transient behavior of passive film is closely related to their protective ability. When passive film formed, the movement of cations 


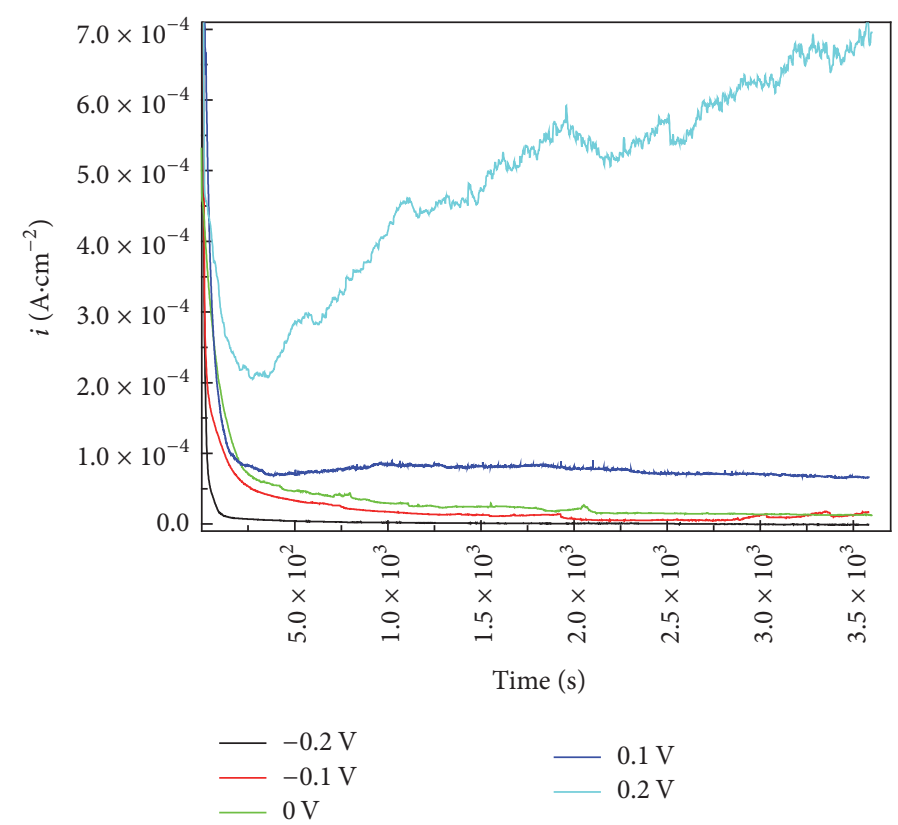

FIgURE 4: Current-time transients for HNSS in $0.05 \mathrm{M} \mathrm{H}_{2} \mathrm{SO}_{4}+0.5 \mathrm{M} \mathrm{NaCl}$ solution.

and/or oxide anions through the passive film becomes the control step of the whole corrosion process [25]. In this case, the ion conductivity becomes a decisive factor to determine the passive current density. It indicates the formation of a compact passive film on the surface of specimen. At an applied potential ranging from -0.1 to $0.1 \mathrm{~V}_{\mathrm{SCE}}$, the superimposed background current is the intermittent anodic current spikes that could be easily distinguished from the background current fluctuations. These current spikes are from either nucleation or metastable pitting events [26]. The steady-state current increased with the applied potentials. When the applied potential is $0.2 \mathrm{~V}_{\mathrm{SCE}}$, the current density will firstly decrease to a minimum value which corresponds to the formation of passive film and then increase gradually which corresponds to pitting nucleation and growth. During this stage, the current is mainly attributed to the dissolution of the alloy and the film formation current with respect to steel dissolution current is relatively smaller. At an applied potential of $0.2 \mathrm{~V}_{\mathrm{SCE}}$, the movement of the cations and/or oxide anions through passive film becomes easier. Thus, the higher passive current density will be obtained on passive films with higher conductivity, indicating their deterioration. Moreover, the penetration force for $\mathrm{Cl}^{-}$through passive films increases with the applied potentials. Once $\mathrm{Cl}^{-}$reached the metal/film interfaces, $\mathrm{MCl}_{x}$ compounds may form and induce the damage of passive films, finally resulting in the increase of current $[4,27]$.

3.3. Semiconducting Nature of the Passive Film. Generally, the passive films formed on most metals and alloys exhibit semiconducting behavior, which can be described by MottSchottky analysis [28]. Mott-Schottky analysis has been employed to determine the semiconductor type and doping density of passive films. The Mott-Schottky equation is given by $[19,24,29-31]$

$$
\frac{1}{C_{\mathrm{SC}}^{2}}=\frac{2}{\varepsilon \varepsilon_{0} q N_{q}}\left(E-E_{\mathrm{fb}}-\frac{k T}{e}\right),
$$

where $C_{\mathrm{SC}}$ is the space charge capacitance, $N_{q}$ is the donor/acceptor density in the passive film, $\varepsilon$ is the dielectric constant of the oxide (usually taken as 15.6 for the passive film on stainless steel $[19,29]), \varepsilon_{0}$ denotes the vacuum permittivity $\left(8.85 \times 10^{-14} \mathrm{~F} \cdot \mathrm{cm}^{-1}\right), q$ is the electron charge, and $k, T$, and $E_{\mathrm{fb}}$ are the Boltzmann constant, absolute temperature, and flat band potential, respectively. The flat band potential can be determined from the extrapolation of the linear portion to $C^{-2}=0$. For a p-type semiconductor, $C^{-2}$ versus $E$ should be linear with a negative slop that is inversely proportional to the acceptor density. On the other hand, an ntype semiconductor yields a positive slope, which is inversely proportional to the donor density.

The Mott-Schottky curves of the HNSS in $0.05 \mathrm{M} \mathrm{H}_{2} \mathrm{SO}_{4}$ $+0.5 \mathrm{M} \mathrm{NaCl}$ at various formation potentials were shown in Figure 5. Although there are slight differences between five curves (may be due to the difference of the samples), they possess the same semiconductor properties and turning potentials of $-0.2,0,0.2$, and $0.65 \mathrm{~V}_{\mathrm{SCE}}$. The Mott-Schottky of HNSS is slightly different from the obtained curves of stainless steels [7, 17, 29, 32]. From the Mott-Schottky curves, it is clear that the electrode has an equivalent flat band potential and possesses $\mathrm{p}$-type and n-type semiconductivity in the same potential ranges. In Figure 5, a positive slope exists due to the oxide film formed on HNSS in the range from -0.3 to $0 \mathrm{~V}_{\mathrm{SCE}}$, indicating the electrochemical behavior of the n-type semiconductor. At the potential ranging from 0 to $0.2 \mathrm{~V}_{\mathrm{SCE}}$, the plots also show a linear tendency. The 


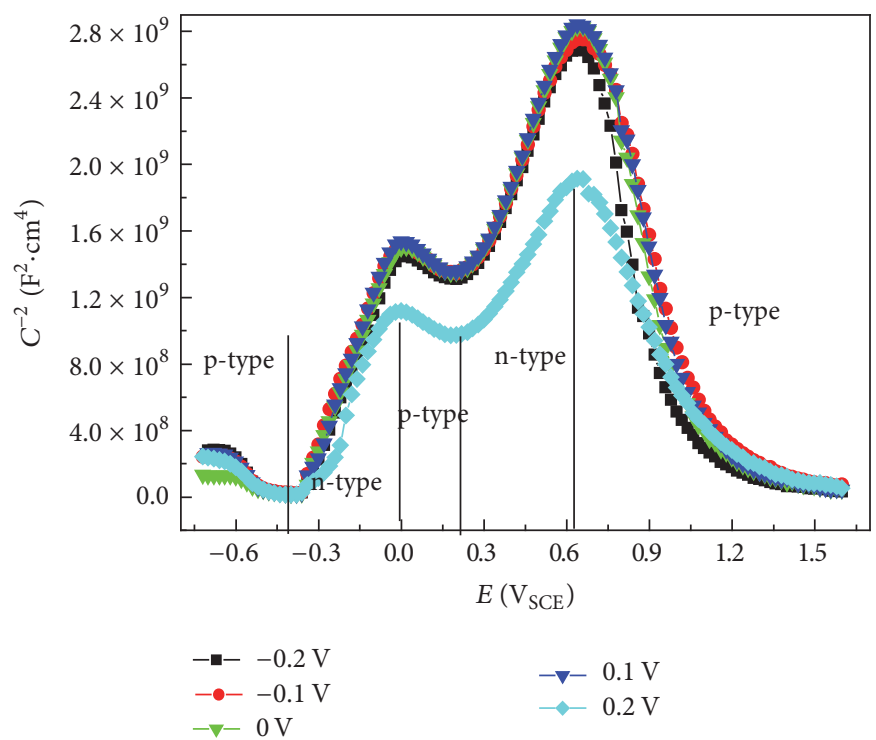

Figure 5: Mott-Schottky plots of $\mathrm{HNSS}$ in $0.05 \mathrm{M} \mathrm{H}_{2} \mathrm{SO}_{4}+0.5 \mathrm{M} \mathrm{NaCl}$ at various potentials.

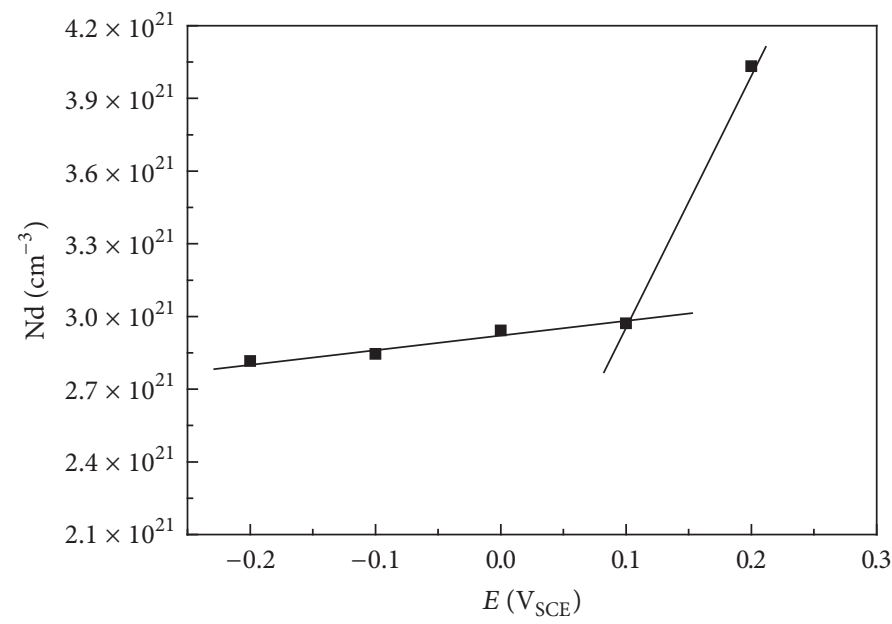

Figure 6: Donor density of the passive films formed on HNSS surfaces at various potentials for $90 \mathrm{~min}$ in $0.05 \mathrm{~mol} / \mathrm{L} \mathrm{H}_{2} \mathrm{SO}_{4}+0.5 \mathrm{~mol} / \mathrm{L} \mathrm{NaCl}$ solution.

passive film possesses p-type semiconductor property due to the negative slope. Such variation of n-type to $\mathrm{p}$-type repeatedly appears at the wide potentials ranging from 0.2 to $0.6 \mathrm{~V}_{\mathrm{SCE}}$ and from 0.7 to $1.2 \mathrm{~V}_{\mathrm{SCE}}$. This phenomenon is probably related to the composition and structure of passive films. The p-type semiconducting behavior is related to the presence of $\mathrm{Cr}_{2} \mathrm{O}_{3}$ in the inner part of passive films [3234]. Virtanen et al. [35] found that chromium vacancies or excess oxygen can be correlated to this p-type semiconductor behavior of chromium oxide in passive films. The n-type semiconducting behavior is related to the presence of $\mathrm{Fe}_{2} \mathrm{O}_{3}$ in the outer part of the passive film. According to Hakiki et al. [15], the first and second slopes are attributed to $\mathrm{Fe}^{2+}$ located, respectively, in the tetrahedral and octahedral sites of a spinel type structure.

It is generally accepted that the stability of the passive film is affected by the concentration of the donor density and the diffusion coefficient. The higher acceptor or donor density will lead to the higher conductivity of the passive film. Figure 6 shows the change in donor concentration with different applied potentials. In the applied potential ranging from -0.2 to $0.1 \mathrm{~V}_{\mathrm{SCE}}$, the donor density increases with the increased applying potentials, but the effect of applied potentials on the donor concentration is not obvious. It also shows that HNSS has a stable passive value at applied potential ranging from -0.2 to $0.1 \mathrm{~V}_{\mathrm{SCE}}$, indicating the degradation of passive films.

3.4. XPS Results. XPS analysis was undertaken to provide more information about the properties of passive films formed on HNSS surfaces. Spectra of the primary compounds of passive film-chromium, iron, manganese, chloride, and oxygen are prepared based on their binding energies (EB). Figure 7 shows the identified elemental spectra in passive films after sputtering for $10 \mathrm{~s}$. The oxide and metallic 


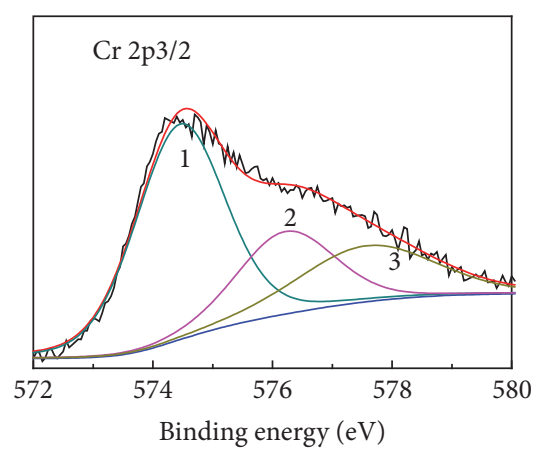
(1) $\mathrm{Cr}$
(2) $\mathrm{Cr}_{2} \mathrm{O}_{3}$
(3) $\mathrm{Cr}(\mathrm{OH})_{3}$

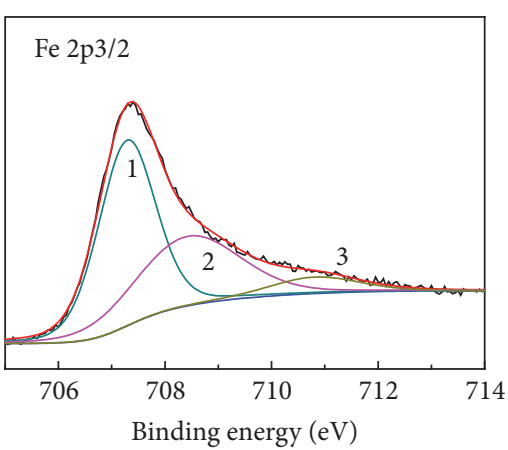

(1) $\mathrm{Fe}$

(2) $\mathrm{Fe}^{2+}$

(3) $\mathrm{Fe}^{3+}$

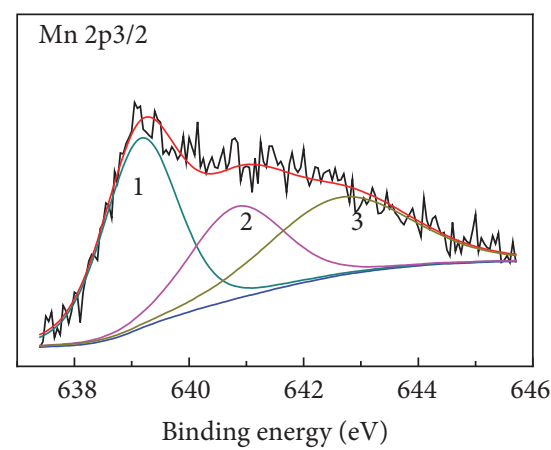

(1) $\mathrm{Mn}^{0}$

(2) $\mathrm{MnO}$

(3) $\mathrm{Mn}_{2} \mathrm{O}_{3}$
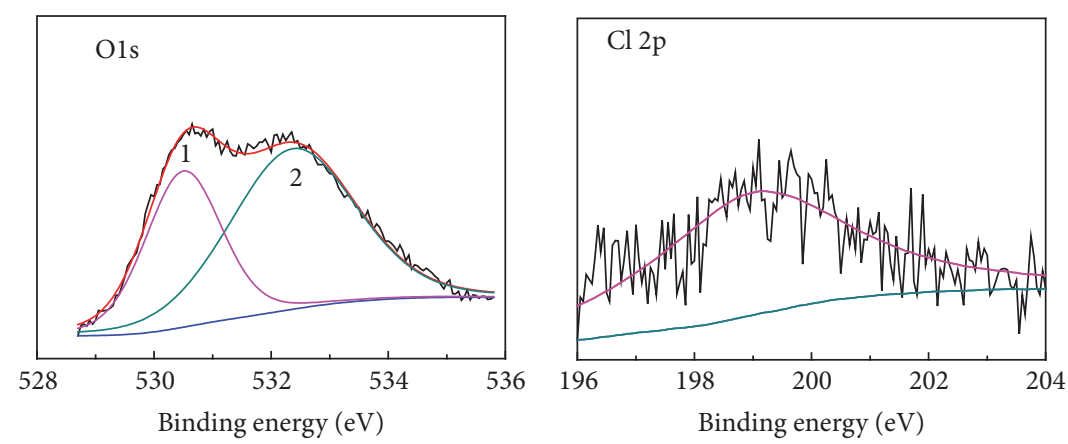

(1) $\mathrm{O}^{2-}$

(2) $\mathrm{OH}^{-}$

Figure 7: ARXPS component analyses of HNSS surface after passivation at $0 \mathrm{~V}$ (SCE) for 90 min in $0.05 \mathrm{M} \mathrm{H}_{2} \mathrm{SO}_{4}+0.5 \mathrm{M} \mathrm{NaCl}$ after sputtering time for $10 \mathrm{~s}$.

states of the alloying elements $\mathrm{Fe}, \mathrm{Cr}$, and Mn were detected. The peak signals of Mo were relatively weak.

In the passivated film obtained in the tested solution, the signals corresponding to the $\mathrm{Cr} 2 \mathrm{p} 3 / 2$ spectra show that there exist three constituent peaks representing metallic state of $\left(\mathrm{Cr}^{0}\right), \mathrm{Cr}(\mathrm{OH})_{3} / \mathrm{CrOOH}$, and $\mathrm{Cr}_{2} \mathrm{O}_{3}[8,14,36-38]$. Similar structures of $\left(\mathrm{Cr}(\mathrm{OH})_{3}+\mathrm{Cr}_{2} \mathrm{O}_{3}\right)$ can be observed in the films formed on stainless steel in the strong $(\mathrm{pH} \mathrm{0.8)}$ and weak ( $\mathrm{pH}$ 5) acid solutions [17]. According to the results reported by Singh and Ray [7], the chromium rich oxide-hydroxide film can be formed on the surface of stainless steels when exposed to acidic environments, which proceeds by solidstate mechanisms as

$$
\begin{aligned}
4 \mathrm{Cr}+3 \mathrm{H}_{2} \mathrm{SO}_{4} & =2 \mathrm{Cr}_{2} \mathrm{O}_{3}+3 \mathrm{SO}_{2}+6 \mathrm{H}^{+}+e \\
\mathrm{Cr}+\mathrm{H}_{2} \mathrm{SO}_{4} & =\mathrm{CrOOH}+\mathrm{SO}_{2}+6 \mathrm{H}^{+}+e
\end{aligned}
$$

The presence of $\mathrm{Cr}^{0}$ indicated that most passive film was bombarded out and the exposed surface was near to bare alloy. The Fe 2p3/2 spectra were made up of three constituent peaks representing the metallic state $\left(\mathrm{Fe}^{0}\right)$, bivalent ( $\left.\mathrm{Fe}(\mathrm{II})\right)$, and trivalent (Fe(III)) species. The peak indicates that Fe(III) is the primary iron oxidized species in passive films. The passive film is mainly comprised of $\mathrm{Fe}_{3} \mathrm{O}_{4}, \mathrm{Fe}_{2} \mathrm{O}_{3}$, and $\mathrm{FeOOH}$.
The O1s spectra can also be split into $\mathrm{O}^{2-}$ and $\mathrm{OH}^{-}$. It can be seen that the peak of $\mathrm{OH}^{-}$corresponds to the formation of $\mathrm{Cr}(\mathrm{OH})_{3} / \mathrm{CrOOH}$ and $\mathrm{FeOOH}$. The peak of $\mathrm{O}^{2-}$ corresponds to the formation of $\mathrm{Cr}_{2} \mathrm{O}_{3}, \mathrm{Fe}_{3} \mathrm{O}_{4}, \mathrm{Fe}_{2} \mathrm{O}_{3}, \mathrm{MnO}$, and $\mathrm{Mn}_{2} \mathrm{O}_{3}$. ARXPS results reveal that chlorides were found in passive film. The detected peak in ARXPS spectrum is due to the absorbed $\mathrm{Cl}^{-}$in passive films. The presence of adsorbed $\mathrm{Cl}^{-}$ on passive films is known to create a concentration gradient that facilitates the diffusion of these ions into films [10, 39]. The transport of $\mathrm{Cl}^{-}$into films will undergo hydrolysis and reduce the local $\mathrm{pH}$, causing the film dissolution $[39,40]$.

ARXPS depth profiles are examined and the results are shown in Figure 8. It can be seen that the concentration of $\mathrm{Cr}$ is higher than that of $\mathrm{Fe}$ in the passive films during the initial stage of sputtering period. In addition, it indicates that the highest concentration of $\mathrm{Cr}$ is observed after sputtering period for $10 \mathrm{~s}$. The $\mathrm{Cr}$ enrichment is due to the preferential dissolution of iron and manganese into the solution and low mobility of chromium in the surface films. Meanwhile, it was also observed that the Fe content increased during the initial stage of the sputtering period in the passive films. After sputtering for $30 \mathrm{~s}$, the concentrations of $\mathrm{Fe}, \mathrm{Cr}$, and $\mathrm{Mn}$ become constant and attain to the alloying proportion, indicating the existence of film/metal interfaces. 


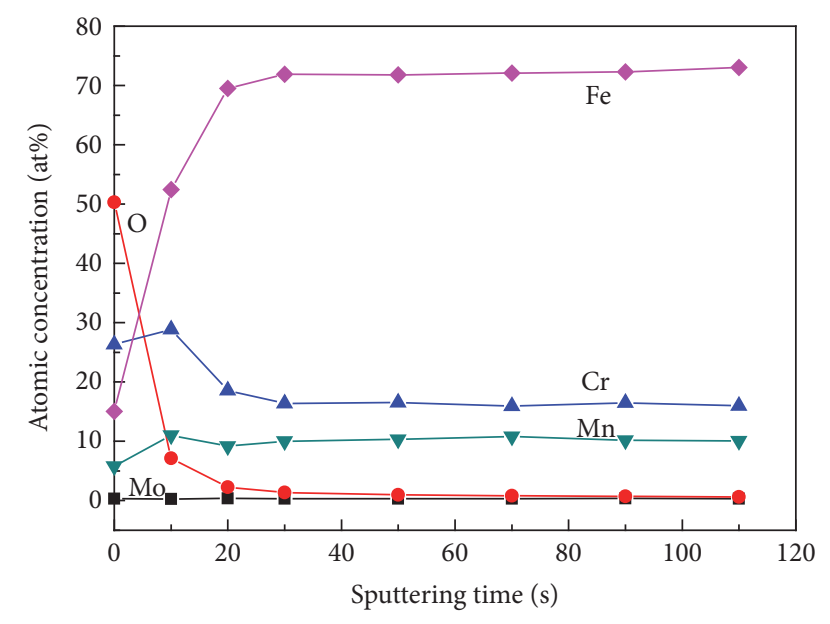

FIGURE 8: ARXPS sputtering depth profiles of alloying elements in passive films of HNSS passivation for $90 \mathrm{~min}$ at $0 \mathrm{~V}_{\mathrm{SCE}}$ in the $0.05 \mathrm{M}$ $\mathrm{H}_{2} \mathrm{SO}_{4}+0.5 \mathrm{M} \mathrm{NaCl}$ solution.

\section{Conclusions}

(1) No obvious pitting corrosion observed even in acidic $\mathrm{NaCl}$ solution, demonstrating that HNSS offered excellent pitting corrosion resistance in corrosive environments. Potentiodynamic polarization in $0.05 \mathrm{~mol} / \mathrm{L}$ $\mathrm{H}_{2} \mathrm{SO}_{4}+0.5 \mathrm{~mol} / \mathrm{L} \mathrm{NaCl}$ has three corrosion potentials.

(2) The Mott-Schottky plot indicated that the surface films of HNSS have both p-type and n-type electronic characteristics. Moreover, the protective ability of passive films decreased with the increase of formation potentials.

(3) APXPS analyses revealed that the primary constituents of passive films formed in $0.05 \mathrm{~mol} / \mathrm{L} \mathrm{H}_{2} \mathrm{SO}_{4}$ $+0.5 \mathrm{~mol} / \mathrm{L} \mathrm{NaCl}$ solution were composed of iron oxides, manganese oxides, $\mathrm{Cr}_{2} \mathrm{O}_{3}$, and $\mathrm{Cr}(\mathrm{OH})_{3}$.

(4) After passivation, no molybdenum oxides were detected in passive films by ARXPS because of their dissolution in the electrolyte, whereas $\mathrm{Cl}^{-}$was incorporated in the formed films.

\section{Competing Interests}

The authors declare no competing interests.

\section{Acknowledgments}

This work was financially supported by National Natural Science Foundation of China (nos. 51401092, 51304041, 51434004, and U1435205) and Fundamental Research Funds for the Central Universities (Grant no. N150204007).

\section{References}

[1] T. Rashev, "High nitrogen steels and metallurgy under pressure," Transactions of the Indian Institute of Metals, vol. 23, no. 6, pp. 201-211, 2002.
[2] Y.-P. Lang, H.-P. Qu, H.-T. Chen, and Y.-Q. Weng, "Research progress and development tendency of nitrogen-alloyed austenitic stainless steels," Journal of Iron \& Steel Research International, vol. 22, no. 2, pp. 91-98, 2015.

[3] H.-B. Li, Z.-H. Jiang, Z.-R. Zhang, B.-Y. Xu, and F.-B. Liu, "Mechanical properties of nickel free high nitrogen austenitic stainless steels," Journal of Iron and Steel Research International, vol. 14, no. 5, pp. 330-334, 2007.

[4] J. R. Galvele, R. M. Torresi, and R. M. Carranza, "Passivity breakdown, its relation to pitting and stress-corrosion-cracking processes," Corrosion Science, vol. 31, pp. 563-571, 1990.

[5] A. Poonguzhali, T. Anita, N. Sivaibharasi, H. Shaikh, and R. K. Dayal, "Effect of nitrogen content on the tensile and stress corrosion cracking behavior of AISI type 316LN stainless steels," Transactions of the Indian Institute of Metals, vol. 67, no. 2, pp. 177-184, 2014.

[6] P. J. Uggowitzer, R. Magdowski, and M. O. Speidel, "High nitrogen steels. nickel free high nitrogen austenitic steels," ISIJ International, vol. 36, no. 7, pp. 901-908, 1996.

[7] V. B. Singh and M. Ray, "The electrochemical behaviour of nitrogen-containing austenitic stainless steel in methanolic solution," Journal of Materials Science, vol. 42, no. 19, pp. 82798286,2007

[8] X. Q. Wu, Y. Fu, W. Ke, S. Xu, B. Feng, and B. T. Hu, "Effects of nitrogen on passivity of nickel-free stainless steels by electrochemical impedance spectroscopy analysis," Journal of Materials Engineering \& Performance, vol. 24, no. 9, pp. 36073614, 2015.

[9] Y. X. Qiao, Y. G. Zheng, P. C. Okafor, and W. Ke, "Electrochemical behaviour of high nitrogen bearing stainless steel in acidic chloride solution: effects of oxygen, acid concentration and surface roughness," Electrochimica Acta, vol. 54, no. 8, pp. 2298-2304, 2009.

[10] H. J. Grabke, "The role of nitrogen in the corrosion of iron and steels," ISIJ International, vol. 36, no. 7, pp. 777-786, 1996.

[11] A. Poonguzhali, M. G. Pujar, C. Mallika, and U. K. Mudali, "Corrosion fatigue behavior of 316LN SS in acidified sodium chloride solution at applied potential," The Journal of the Minerals, Metals \& Materials Society, vol. 67, no. 5, pp. 1162-1175, 2015.

[12] Y. Fu, X. Wu, E.-H. Han, W. Ke, K. Yang, and Z. Jiang, "Effects of nitrogen on the passivation of nickel-free high nitrogen and manganese stainless steels in acidic chloride solutions," Electrochimica Acta, vol. 54, no. 16, pp. 4005-4014, 2009.

[13] R. Mohammed, G. M. Reddy, and K. S. Rao, "Microstructure and pitting corrosion of shielded metal arc welded high nitrogen stainless steel," Defence Technology, vol. 11, no. 3, pp. 237-243, 2015.

[14] A. R. Brooks, C. R. Clayton, K. Doss, and Y. C. Lu, "On therole of $\mathrm{Cr}$ in the passivity of stainless steel," Journal of the Electrochemical Society, vol. 133, no. 12, pp. 2459-2464, 1986.

[15] N. E. Hakiki, M. Da Cunha Belo, A. M. P. Simoẽs, and M. G. S. Ferreira, "Semiconducting properties of passive films formed on stainless steels: influence of the alloying elements," Journal of the Electrochemical Society, vol. 145, no. 11, pp. 3821-3829, 1998.

[16] S. Ningshen, U. K. Mudali, V. K. Mittal, and H. S. Khatak, "Semiconducting and passive film properties of nitrogen-containing type 316LN stainless steels," Corrosion Science, vol. 49, no. 2, pp. 481-496, 2007.

[17] C. T. Liu and J. K. Wu, "Influence of $\mathrm{pH}$ on the passivation behavior of $254 \mathrm{SMO}$ stainless steel in $3.5 \% \mathrm{NaCl}$ solution," Corrosion Science, vol. 49, no. 5, pp. 2198-2209, 2007. 
[18] W. Ye, Y. Li, and F. Wang, "Effects of nanocrystallization on the corrosion behavior of 309 stainless steel," Electrochimica Acta, vol. 51, no. 21, pp. 4426-4432, 2006.

[19] A. Fattah-alhosseini, M. A. Golozar, A. Saatchi, and K. Raeissi, "Effect of solution concentration on semiconducting properties of passive films formed on austenitic stainless steels," Corrosion Science, vol. 52, no. 1, pp. 205-209, 2010.

[20] M. J. Carmezim, A. M. Simões, M. O. Figueiredo, and M. Da Cunha Belo, "Electrochemical behaviour of thermally treated Cr-oxide films deposited," Corrosion Science, vol. 44, no. 3, pp. 451-465, 2002.

[21] R. De Gryse, "On the interpretation of Mott-Schottky plots determined at semiconductor/electrolyte systems," Journal of the Electrochemical Society, vol. 122, no. 5, pp. 711-712, 1975.

[22] G. L. Griffin, "Simple phase transition model for metal passivation kinetics," Journal of the Electrochemical Society, vol. 131, no. 1, pp. 18-21, 1984.

[23] P. L. Andresen and F. P. Ford, "On the modeling of stress corrosion cracking of iron and nickel base alloys in high temperature aqueous environments," Corrosion Science, vol. 38, no. 6, pp. 1011-1016, 1996.

[24] C. Li, X. Cheng, C. Dong, Z. Jia, and X. Li, "Study on the effect of $\mathrm{PbO}$ on the passive behavior of alloy 690 in sodium hydroxide aqueous solution," Acta Metallurgica Sinica (English Letters), vol. 23, no. 5, pp. 343-350, 2010.

[25] T. P. Hoar, "The production and breakdown of the passivity of metals," Corrosion Science, vol. 7, no. 6, pp. 341-355, 1967.

[26] G. O. Ilevbare and G. T. Burstein, "Role of alloyed molybdenum in the inhibition of pitting corrosion in stainless steels," Corrosion Science, vol. 43, no. 3, pp. 485-513, 2001.

[27] P. C. Pistorius and G. T. Burstein, "Growth of corrosion pits on stainless steel in chloride solution containing dilute sulphate," Corrosion Science, vol. 33, no. 12, pp. 1885-1897, 1992.

[28] S. M. Wilhelm and N. Hackerman, "Photoelectrochemical characterization of the passive films on iron and nickel," Journal of the Electrochemical Society, vol. 128, no. 8, pp. 1668-1674, 1981.

[29] A. Fattah-Alhosseini, A. Saatchi, M. A. Golozar, and K. Raeissi, "The passivity of AISI 316L stainless steel in $0.05 \mathrm{M} \mathrm{H}_{2} \mathrm{SO}_{4}$," Journal of Applied Electrochemistry, vol. 40, no. 2, pp. 457-461, 2010.

[30] S. Yang and D. D. Macdonald, "Theoretical and experimental studies of the pitting of type 316L stainless steel in borate buffer solution containing nitrate ion," Electrochimica Acta, vol. 52, no. 5, pp. 1871-1879, 2007.

[31] M. J. Carmezim, A. M. Simões, M. F. Montemor, and M. Da Cunha Belo, "Capacitance behaviour of passive films on ferritic and austenitic stainless steel," Corrosion Science, vol. 47, no. 3 , pp. 581-591, 2005.

[32] N. B. Hakiki, S. Boudin, B. Rondot, and M. Da Cunha Belo, "The electronic structure of passive films formed on stainless steels," Corrosion Science, vol. 37, no. 11, pp. 1809-1822, 1995.

[33] F. Gaben, B. Vuillemin, and R. Oltra, "Influence of the chemical composition and electronic structure of passive films grown on 316L SS on their transient electrochemical behavior," Journal of the Electrochemical Society, vol. 151, no. 11, pp. B595-B604, 2004.

[34] N. E. Hakiki, M. F. Montemor, M. G. S. Ferreira, and M. Da Cunha Belo, "Semiconducting properties of thermally grown oxide films on AISI 304 stainless steel," Corrosion Science, vol. 42, no. 4, pp. 687-702, 2000.

[35] S. Virtanen, P. Schmuki, H. Böhni, P. Vuoristo, and T. Mäntylä, "Artificial $\mathrm{Cr}$ - and $\mathrm{Fe}$-oxide passive layers prepared by sputter deposition," Journal of the Electrochemical Society, vol. 142, no. 9, pp. 3067-3072, 1995.

[36] C. R. Clayton and Y. C. Lu, "Bipolar model of the passivity of stainless steel: the role of Mo addition," Journal of the Electrochemical Society, vol. 133, no. 12, pp. 2465-2473, 1986.

[37] I. Olefjord, B. Brox, and U. Jelvestam, "Surface composition of stainless steels during anodic dissolution and passivation studied by ESCA," Journal of the Electrochemical Society, vol. 132, no. 12, pp. 2854-2861, 1985.

[38] B. Stypula and J. Stoch, "The characterization of passive films on chromium electrodes by XPS," Corrosion Science, vol. 36, no. 12, pp. 2159-2167, 1994.

[39] C.-O. A. Olsson and D. Landolt, "Passive films on stainless steels-chemistry, structure and growth," Electrochimica Acta, vol. 48, no. 9, pp. 1093-1104, 2003.

[40] Y. C. Lu, M. B. Ives, and C. R. Clayton, "Synergism of alloying elements and pitting corrosion resistance of stainless steels," Corrosion Science, vol. 35, no. 1-4, pp. 89-96, 1993. 

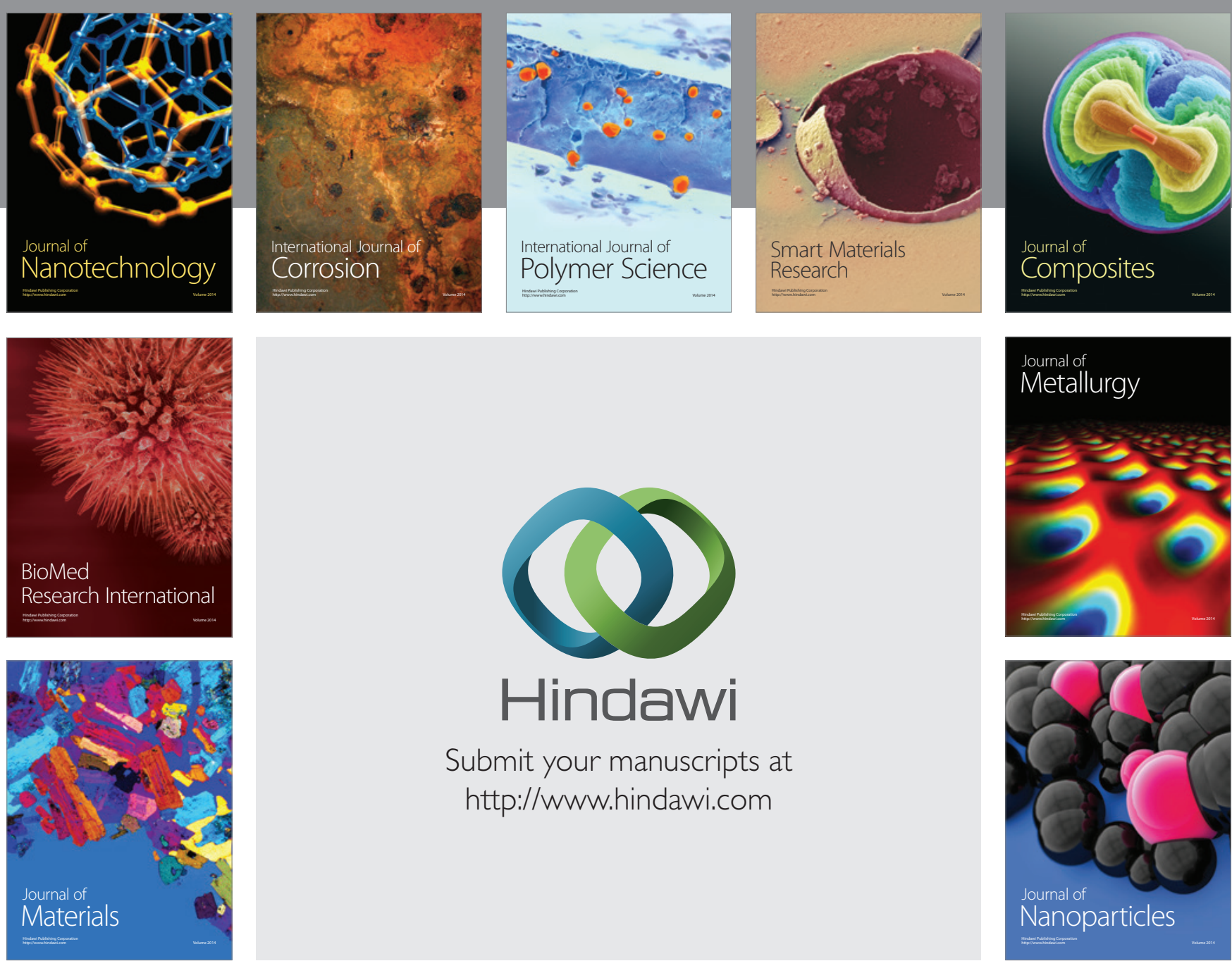

\section{Hindawi}

Submit your manuscripts at

http://www.hindawi.com

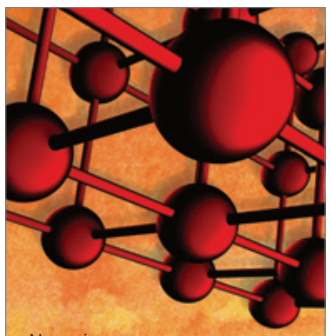

Materials Science and Engineering
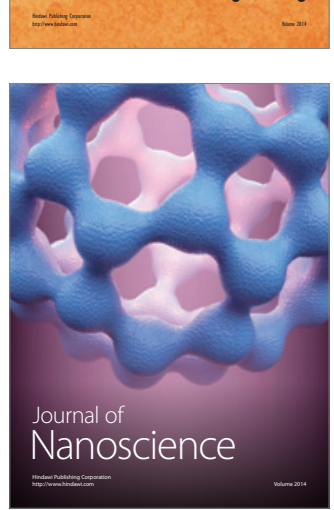
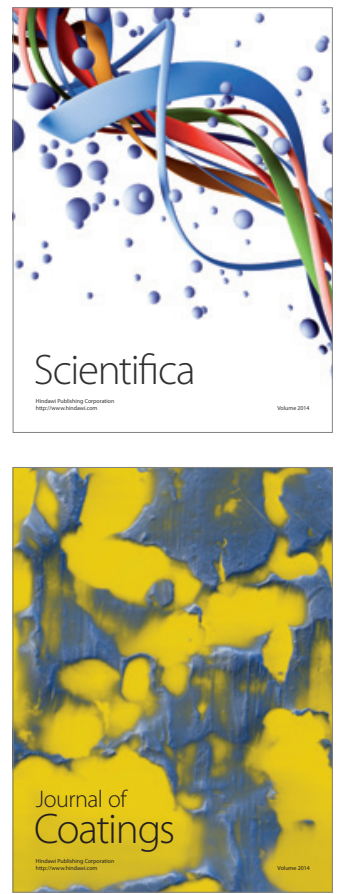
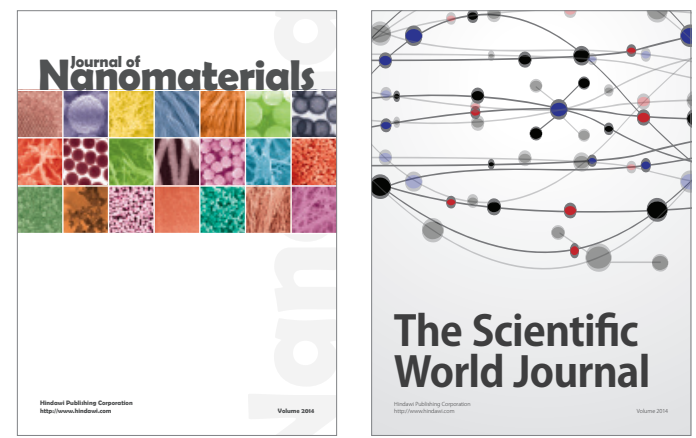

The Scientific World Journal
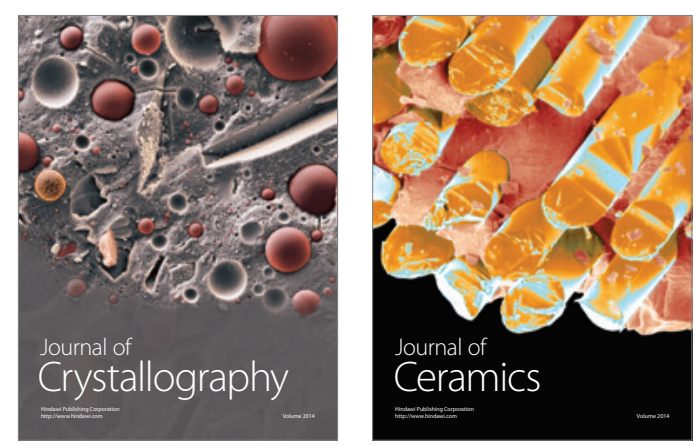
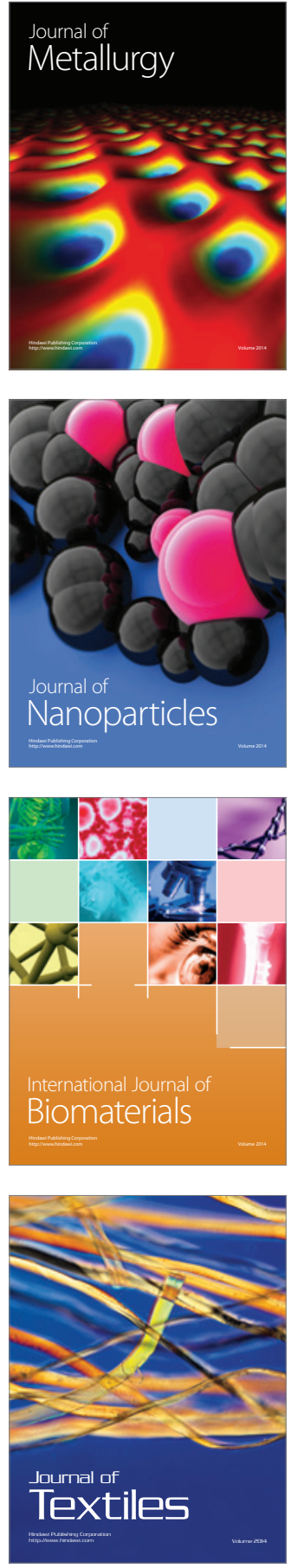